the bornugh of Bexley and with the Medical Architecture Research Unit at Southend (Director, Mr Raymond Moss) and the General Practice Advisory Service (Architect, Mr. Brian Brookes). None of the hospital services envisaged in the overall plan is now involved, but otherwise the brief reflects in miniature the ultimate aims of the project.

The design of the first huilding was influenced by a number of important factors:

1. The need to be self-sufficient, taking account of the possibility of some changes in function as the total pattern of health facilities grows.

2. The town-planning principle of segregation of pedestrians and vehicular traffic by means of a pedestrian deck at first-flomr level: all traffic (hut nnlv a small numher of pedestrians) will approach the buildeng at ground level.

3. The site location (bordering on an artificial lake near one of the develnpment subcentres) and size (rather less than the floor area required).

The architect's solution was to raise the main accommodation on a concrete deck to first-floor level (that is, pedestrian-deck level), leaving the ground foor for vehicle passenger entrance, service rooms, stores, and a pram park for the minority of pedestrians who approach from a near-hy bus stop and from the subcentre via the lake walk. Car park- ing is provided at this level under cover of the pedestrian deck above.

Patients and staff arriving at this level can reach the main accommodation by means of lift or staircase, which discharges adjacent to the main pedestrian entrance at first-flonr level. Immediately facing the patient on entry is the reception desk, which has visual control of the three sides of the square-ring corridor. After registering, patients wait in the adjacent general or dental waiting-rooms (which include a children's playroom) and are called down the east and west corridors respectively to consulting- and treatmentrooms.

\section{Consulting-rooms}

General consulting-rooms are served by a treatment room, specimen room, and laboratory ; in addition, they share a supply store and disposal room with the dental suite. A small local waiting space is provided for patients passing from consulting- to treatmentroom or-in the case of antenatal clinicsin the opposite direction.

Dental patients pass from the main waiting area, down the west corridor, where they are met by the dental nurse. After treatment they may return by way of the main entrance, or, if a general anaesthetic has been necessary, they may use the exit adjacent to the dental suite, which is also used by the dental staff.

A separate exit for staff is provided by the escape stair in the north-east corner, allowing them to arrive or leave without passing the main waiting area (see plan).

It will be noticed that rooms around the perimeter are those requiring a view and natural light but no other special environmental requirements; ronms in the core of the building would not benefit from a view, but do require special ventilation of one sort or another. Neither the consulting-rooms on the east side, nor the dental surgeries on the north, are overlooked, since they face the lake.

The temporary mobile health centre has a demountable structure, consisting of four single-sternye timher units, each the size of a large caravan and containing part of the health centre accommodation, fully equipped. These units are simply carried to the site on a trailer, set down on their skids and connected by additional floor elements which form waiting and corridor spaces.

\section{RBPBRENCBS}

1 Brit. med. F., 1966, 2, 1386. Butterfield, W. H. J., Lancet, 1966, 1, 650 J.,

\title{
CONFERENCES AND MEETINGS
}

\section{Operating-rooms a Century after Lister: B.M.A. Symposium}

A Lister Commemoration Symposium on operating-theatre decign was held at B.M.A. House on 8 Decemher, under the chairmanship of the President, Mr. R. V. CoOke.

Opening the symposium. the Minister of Health, Mr. KENNETH RoBINSON, referred to Lord Lister as one of the twelve people who had done most to relieve human suffering. At the present time new hospital buildings worth $\$ 230 \mathrm{~m}$. were under construction. In the interests of economy, speed of construction, efficiency, and gond design his Ministry was now developing standardized plans for operating departments, but this would not mean stagnation. Alternatives were provided, and designs would be continually brought up to date.

Concluding the opening addresses, Professor Sir HedlFy AtKins, P.R.C.S., outlined Lord Lister's long association with the B.M.A.extending from 1863, the year after his qualification, to his death in 1912. Within a month of I ister's puhlication of his second Lancet article, in 1867, the Ascociation had invited him to address their Durlin meeting. He hecame president of the surgical section in 1870, and firs descrihed the famous carbolic snray at the Plymouth meeting of 1871 . Although relations with the BM.A. were subsequentlv less gond for a time-largely owing to the activities of the then editor of the British Medical Fournal-amitv was later restored, and a special Lister issue of the B.M.F. appeared early in the present century.

\section{[From a Special Correspondent]}

\section{Wound Infection}

The first speaker in the symposium itself was Professor R. E. O. Williams (St. Mary's Hospital Medical School, London), whose subiect was wound infection. The overall incidence of this was about $6.7 \%$, but this figure concealed wide variations between different hospitals and operations-from $18 \%$ to $17 \%$, according to hospital, and from $1 \%$ or less for orthopaedic operations to $15 \%$ for gall-hladder surgery. Infection acquired in the theatre probably accounted for ahout $20 \%$ of all wound sepsis, though the proportion might be as high as $50 \%$ for prolnnged thoracic surgical procedures.

The source of infection varied with the tyne of organism. Staphvlococcus aureus commonly came from the nose or skin of the patient or hospital staff, and the carrier rate in patients rose from $35 \%$ to $50 \%$ while in hospital Two per cent. of patients carried penicillin-resistant strains on admission, but the proportion could rise to $20 \%$ or $30 \%$ during a prolnnged stay. Prohably postoperative wnund sepsis with Staph. aureus was commoner in patients who were or had been carriers; during prolonged operations some hacteria almost inevitably fell into the wound. and manv of these were the patient's own staphylnencei.

Three other organisms-Ercherichia coli, Pseudomonas aeruginosa, and Clostridium velchii-could also cause self-infection. The major source was intestinal, but Ps. aeruginosa bred in moist environmental reservoirs such as sinks, sluices, and humidifiers ; to a lesser extent this was also true of $E$. coli and perhaps $\mathrm{Cl}$. welchii. A study of 20 patients with postoperative gas gangrene had shown that 18 followed lower-limb operations, 11 of them amputations. The antiseptics used had heen ineffective against clostridial spores, and no prophylactic penicillin had been given. $\mathrm{Cl}$. welchii was normally present in the intestine, and operations on the upper leg were readily contaminated from the anus. By contrast, $\mathrm{Cl}$. tetani infection was almost always due to faulty sterilization-often of dressings or glove powder.

\section{Preventive Measures}

Professor Williams concluded by recommending preventive measures-proper sterilization for tetanus, suitable antiseptics and chemoprophylaxis for gas gangrene, and careful control of humidifiers and other moist areas for prevention of pseudomonas or $E$. coli infection. Staph. aureus presented more complex problems involving control of carriers and skin spread.

Some of these were covered by the second speaker, Professor R. A. Shooter (St. Bartholomew's Hospital, London)-speaking on dispersal of bacteria-who suggested that adoption of the measures proposed by Professor Williams would reduce the incidence 
of operating-room sepsis to $1 \%$ or less. Showers did not control this dispersal from the skin; greater numbers of bacteria were shed for one and a half hours after a shower, and the effect of adding hexachlorophane was inconstant. Ordinary theatre gowns did not reduce the number of organisms put out, though the level was low and perhaps immaterial except in high-risk operations. Special operating suits made from very closely woven material and worn with plastic bags enclosing the feet and trouser-bottoms were more successful ; ultraviolet light could also help, though it was not fully effective when used alone. A combination of both methods was best, probably because dispersal of bacteria-laden skin scales was prevented, and individual organisms penetrating the finely woven material were killed by ultraviolet irradiation. The special suits and plastic foot-bags also cut down bacterial dispersion from nurses compared with conventional skirts and gowns.

Dispersal from inanimate objects was another danger. In the case of sterile packs, it had been found that opening a singlelayered wrapper threw bacteria from the outside into the air ; these landed on the instruments in 132 out of 250 packs tested. Substitution of a double-layered pack reduced contamination to 1 in 100 . Finally, trials of paper sacks (sealed by stapling) for removal of all contaminated material from operating-rooms had shown that no bacteria escaped on handling or even when the bags were dropped. The special routes for removal of contaminated material now incorporated in many new theatres appeared to be unnecessary.

\section{Ventilation}

Dr. O. M. Lidwell (Medical Research Council) said that operating-theatre ventilation systems had so often been to blame for wound infection in the past that they were now commonly made the scapegoat. In fact the number of pathogenic bacteria likely to reach an operation site by the airborne route was very small-perhaps one or two organisms-but even this might be enough to cause infection in the presence of sutures or other foreign bodies, of microscopic areas of dead tissue, or blood clots. Asepsis could be approached but never fully achieved.

Among measures to reduce airborne spread of infection, Dr. Lidwell emphasized the importance of doors. The airflow through an open doorway might be 1,000 cubic feet $(25.5 \mathrm{cu} . \mathrm{m}$.) per minute-and the doorless openings in some older theatres were a definite risk. Other important factors were reduction of temperature difference heeween the theatre and the neighbouring rooms, and the maintenance of positive air pressure in the operating-roem so that air could leak only outwards around doors and other openings. This required a ventilation system delivering at least 1,000 cubic feet of air per minute, which could both prevent the ingress of airborne bacteria and help to remove those released in the theatre. To avoid the risk of pseudomonas or perhaps $E$. coli infection steam or spinning disc humidifiers could be used in ventilation systems. The incoming air was usually passed through a filter down to 5 microns and introduced at ceiling level, but attempts to direct it around the operating area had met with only moderate success in reducing the number of airborne bacteria.

Concluding Dr. Lidwell showed that a good ventilation system could enhance working capacity by accurate control of temperature, but studies of comfort at different temperature levels had revealed some individual variation. Anaesthetists preferred to be about $4^{\circ} \mathrm{F}$. $\left(2^{\circ}\right.$ C.) warmer than surgeons, for instance, while a few of the latter felt too hot unless the temperature was reduced to the low sixties.

An aseptic operating enclosure for use in hip-prosthesis surgery was described by $\mathrm{Mr}$. J. Charnley (Wrightington Hospital, near Wigan, Lancs), who emphasized the need for absolute sterility in this type of operation. The use of a $7-\mathrm{ft}$. $(2.1 \mathrm{~m}$.) square transparent enclosure within a larger theatre had made possible the provision of a downward stream of sterile air at the rate of 300 air changes per hour without high cost or inconvenience. Only the surgeon, two assistants, and one sister worked within the enclosure, their expired air being withdrawn by suction appliances, worn under complete face and head masks, and removed by vacuum tubes down the back. The flow of 5 cubic feet $(0.2$ cu. m.) per minute under the mask had a markedly refreshing effect and reduced sweating, in addition to removing nose or throat bacteria. The patient's head was outside the enclosure, as were the anaesthetist and the rest of the theatre staff.

The ventilation system was situated immediately above the theatre and opened into the ceiling of the enclosure through an aperture 5 feet $(1.5 \mathrm{~m}$.) square. The lights were situated at the corners of this to avoid turbulence in the downward airflow, which was barely noticeable at a velocity of $1 \frac{1}{2}$ feet $(45.7 \mathrm{~cm}$.) per second. Deflection caused by the presence of the patient was beneficial, since the flow then tended to be away from the operation site towards the surgeon. Similarly there was always an outwards current of air through the instrument hatch and other openings. Other precautions were double gloves, separately sterilized instrument containers for each of the seven stages of the operation, and sterilization of the patient's skin with $2 \%$ iodine-after a skin test. This was followed by a varnish spray to fix potentially infected epithelial squames that might separate during operation.

Concluding, Mr. Charnley pointed out the simplicity of the method and the ease with which spectators could observe operations from outside the enclosure. He believed that such enclosures could be used in any roomseveral being supplied from a single autoclave by people in everyday clothes. This would be cheaper and better than expensive attempts at partial cleanliness, for there was nothing between totally sterile and dirty.

\section{Operating-theatre Design}

Mr. Walpole Lewin (Cambridge) spoke on factors in theatre design and gave three reasons for failure to reduce the morbidity of operative infection. These were overconfidence in conventional aseptic ritual ; complex procedures involving many people and prolonged exposure ; and long waiting-lists. Bed turnover rather than quality had become the criterion of surgical excellence. The load on theatre staffs was excessive, and there was a danger that the "dirty" cases at the end of one surgeon's list would be too closely followed by the important early cases of another surgeon using the same theatre. It took time to clean a theatre properly, and as Lister had said, "Asepsis in this imperfect world is not to be trusted."

It was the surgeon's duty to maintain theatre discipline and exclude infection. Attention had to be given to many factors, including postponement of operations on patients with colds or other infections, use of prophylactic antibiotics, and the wearing of double gloves and gowns covering back and front for all theatre staff. The patient's clothing and theatre trolley should be clean, and too much clutter of staff and apparatus should be avoided. Special equipment-often necessary nowadays-could perhaps be housed outside the theatre proper in adjacent rooms. Finally, humidity, ventilation, and temperature had all to be controlled, and a refrigeration plant was indispensable.

Mr. Walpole Lewin ended by suggesting that the best type of theatre to build at present might be space, in which functional areas could be adjusted to incorporate later developments. The accepted figure of 400 square feet (53 sq. m.) was too small for some operations, and there was a danger that all the work on theatre design since the war might be lost in Ministry standardization, if financial rather than surgical considerations were allowed to predominate.

Speaking as an architect, Mr. J. WeEks (Bartlett School of Architecture, University of London) warned surgeons to be on their guard against architects' running away with ideas. The year 1963, the year of the Royal College of Surgeons' symposium on operating theatre design, had seen the peak of complexity, with every whim indulged, but since then two developments had taken place. Firstly, this complexity of design had become "frozen," and it was now enshrined by the Ministry of Health ; and, secondly, accurate measurements had been made of the needs and functions of an operating-theatre. Some of the elaboration going into theatres at present was no longer necessary-though well adapted to intensive use and modern techniques, they were likely to be superseded. Micro-environments might prove more economical than large operating suites with porters hurtling up and down the sterile corridors. Detailed plans were always apt to become "dated"; and simpler suites with anaesthetic and recovery rooms and reserve space between the theatres should provide for future adaptation. If the original building was suitably constructed, later expansion could be on to different floors as well as on the same level. Concluding, Mr. Weeks said that architects and others thought in 1963 that they knew all the answers to operatingtheatre design-in 1967 they were quite sure they did not.

The last speaker, Major IAN CAPPERAULD, R.A.M.C., described a portable tent-type operating-theatre with special lighting, ventilation, and electrical equipment, used recently at the Royal Herbert Hospital, Woolwich, while the theatres were temporarily closed for alterations. This theatre, together with many exhibits of modern designs for operating departments, was on show in the Great Hall during the symposium. 